\title{
Examining Waterways Near UF Campus for Antimicrobial Resistance
}

\author{
Emily K. Stone \\ College of Agricultural and Life Sciences
}

Faculty Mentor: Julie L. Meyer, Soil and Water Sciences Department

\begin{abstract}
The use of clinical antibiotics has greatly increased the scope and severity of naturally occurring antimicrobial resistance (AMR) patterns. Processing of wastewater by wastewater treatment plants (WWTPs) reduces but does not eliminate the concentration of clinical antibiotics present. Bacterial communities residing in aquatic biofilms are more easily able to exchange genes than their planktonic counterparts and thus display a higher rate of AMR. Previous work has indicated the presence of clinical antibiotics and AMR genes in several aquatic systems worldwide. Gainesville, FL has a significant population density and is home to the state's third-largest hospital as well as a major university; thus, environmental monitoring for AMR genes is a pertinent undertaking. Biofilms were sampled from sites along the Sweetwater Branch Creek upstream and downstream of the GRU Main Street Water Reclamation Facility (WWTP). Colonies were screened for resistance on R2A plates containing ampicillin, methicillin, or vancomycin. After four days, colonies were randomly selected for genetic analysis via polymerase chain reaction (PCR) and gel electrophoresis to detect corresponding antimicrobial resistance genes. Only two colonies of thirty-five were positive for AMR genes: one colony from the downstream site which displayed the $\operatorname{ampC}$ gene for ampicillin resistance and one upstream isolate which displayed the $v a n A$ gene for vancomycin resistance. The preliminary results of this sampling project indicate only a small amount of resistance present along the Sweetwater Branch Creek, though AMR dynamics may be better illuminated by further analysis.

Keywords: biofilm, antimicrobial resistance, AMR, wastewater treatment plant (WWTP), Gainesville
\end{abstract}

\section{Introduction}

\section{Antimicrobial Resistance (AMR) Overview}

Although antimicrobial resistance (AMR) has garnered increasing national attention in the last decade, it has been recognized since the development of the first antibiotics for human use. While AMR patterns are best understood to the general public as issues in healthcare and agriculture, they have also had serious effects on the environment. Previous work by Knapp et al in the Netherlands demonstrated that the abundance of AMR genes in soil has increased as much as fifteen-fold from 1940 to 2008 (Knapp et al, 2010). The environment itself serves as both a 
reservoir for resistance genes as well as antimicrobial compounds. The vast majority of clinical antibiotics have been derived from compounds produced by bacteria and fungi. Resistance is a naturally occurring property in the microbial world; many species are resistant to antimicrobial compounds, including antibiotics, that they or other species produce.

There is no one route through which resistance develops. Bacteria mainly become resistant through horizontal gene transfer (HGT) methods, including conjugation, transformation, and transduction (von Winterdorff et al, 2016). During conjugation, plasmids are exchanged during cell-to-cell contact; this contact may occur between closely related species as well as phylogenetically distant species (Balcázar, Subirats, \& Borrego, 2015). Transformation occurs when competent individuals take up free DNA from their environment and incorporate it into their own genome (von Wintersdorff et al, 2016). While some groups, like Neisseria spp, are generally competent to perform transformation, others may only become competent in certain conditions or in the presence of antibiotics (von Wintersdorff et al, 2016). In transduction, resistance genes are transferred from one bacterial cell to another via bacteriophage (von Wintersdorff et al, 2016).

\section{Antimicrobial Resistance (AMR) in Waterways}

While resistance is natural, its incidence and severity have been greatly increased by the misuse and poor management of antibiotics in healthcare and agriculture as well as the anthropogenic pollution of the environment with clinical antibiotics. According to the WHO, the use, misuse, and overuse of antibiotics has caused an increase in resistance worldwide (World Health Organization, 2014). In the United States, previous work has demonstrated a significant increase in the hospital use of several antibiotic classes, including cephalosporins, glycopeptides, beta lactams, and others (Baggs et al, 2016). Worldwide, the use of antibiotics increased 36\% from 2000-2010 (Van Boeckel et al, 2014). Additionally, it has been estimated that up to onethird of antibiotics are prescribed unnecessarily (Nelson et al, 2021). Various agricultural studies have established a significant association between antimicrobial treatments and the presence of AMR bacteria in both humans and livestock, and the administration of antibiotics in agriculture is expected to increase 67\% by 2030 (Van Boeckel et al, 2015).

The anthropogenic pollution of natural systems by antibiotics is extensive, including both terrestrial and aquatic environments. Though often found in surface water and wastewater, clinical antibiotics have also concerningly been detected in groundwater (Zhang XX, Zhang T, \& 
Fang, 2009). Wastewater treatment plants (WWTPs) have been implicated as a major avenue by which antibiotics are introduced into the environment (Aubertheau et al, 2017).

Previous work has demonstrated that concentrations of antibiotics remain high in WWTP effluent even after treatment of inflowing (upstream) wastewater (Marti, Jofre, \& Balcazar, 2013; Lien et al, 2016). The use of UV treatment and sand filtration are mostly ineffective at reducing the concentration of antibiotics present in effluent; chlorination may significantly reduce the concentration of antibiotics present, but the efficiencies of all methods vary (Kulkarni et al, 2017; Burch et al, 2019). Even in a low concentration, the presence of antibiotics can affect normal bacterial function, promoting horizontal gene transfer, recombination, and mutation (Chow, Waldron, \& Gillings, 2015; Balcázar, Subirats, \& Borrego, 2015). AMR genes have also been detected worldwide in a variety of water systems (Zhang, XX., Zhang, T., \& Fang, 2009). Again, wastewater has been implicated as a major reservoir of AMR genes, including reclaimed wastewater (Marti, Variatza, \& Balcázar, 2014; Fahrenfeld et al, 2013).

\section{Antimicrobial Resistance (AMR) in Aquatic Biofilms}

An important reservoir for resistance genes in aquatic systems is the biofilm. Biofilms have many vital functions, including the breakdown of organic compounds and biogeochemical

cycling (Balcázar, Subirats, \& Borrego, 2015). They are ubiquitous, complex structures produced by bacteria, composed mainly of an exopolysaccharide (EPS) layer augmented with other microbial compounds. These aggregates provide their constituent species with protection from the environment and are often densely populated, allowing increased opportunities for gene exchange (Gebreyohannes et al, 2019).

Previous work has determined that experimental rates of conjugation may be 1000x greater in biofilms than on traditional plates (Balcázar, Subirats, \& Borrego, 2015). Resistance genes can persist in biofilms more readily than in water or sediment (Guo et al, 2018). The vancomycin resistance gene $v a n A$ has been detected in biofilms even without the presence of enterococcal species known to be resistant, indicating a possible transfer to autochthonous species (Schwartz et al, 2003). Subsequently, resistant bacteria are isolated more often from biofilms than other areas of the aquatic environment (Maal-Bared et al, 2013).

\section{Antibiotic Resistance Mechanisms}

There are many classes of antibiotics, each with unique associated mechanisms of resistance. In this study, bacterial colonies were screened for resistance to antibiotics from two classes: beta- 
lactams (ampicillin and methicillin) and glycopeptides (vancomycin). The mechanisms which give rise to resistance in all three antibiotics have been well-documented and are often associated with specific genes: ampC for ampicillin, mecA in methicillin, and vanA in vancomycin.

Both classes are effective against Gram-positive bacteria, or those which have a cell wall composed of the protein peptidoglycan (Kapoor, Saigal, \& Elongavan, 2017). Ampicillin functions by disrupting the synthesis of peptidoglycan (Kaushik et al, 2014). It can be prescribed to treat a wide range of bacterial infections, including S. aureus, E. coli, and H. pneumoniae (Kaushik et al, 2014). The ampC gene encodes resistance to various beta-lactams, including ampicillin (Griffin et al, 2020). Methicillin, like ampicillin, disrupts the synthesis of peptidoglycan in bacteria (Stapleton \& Taylor, 2007). Resistance to methicillin is commonly seen in staphylococcal species, namely $S$. aureus, which alter the makeup of penicillin binding protein-2 (PBP-2) to prevent methicillin from binding to it (Stapleton \& Taylor, 2007; Chambers, 1997). The mecA gene has been detected with frequency from biofilms grown in hospital wastewater (Zhang, XX., Zhang, T., Fang, 2009; Schwartz et al, 2003). When methicillin resistance is present, vancomycin is often prescribed. Vancomycin also affects peptidoglycan, though its mode of action involves capping the D-alanine-D-alanine (D-Ala-DAla) terminus of peptidoglycan to prevent crosslinking (Courvalin, 2006). The vanA gene, which encodes vancomycin resistance, does so by replacing D-Ala-D-Ala with D-alanine-D-lactate (DAla-D-Lac) (Courvalin, 2006).

\section{Project Overview}

Here, biofilms from local waterways in Gainesville, FL were screened for the presence or absence of AMR genes via traditional culturing techniques and genetic analysis. Bacterial isolates were screened for resistance to vancomycin, ampicillin, and methicillin. All three antibiotics are vitally important in healthcare and have well-characterized AMR genes (Knapp et al, 2010; Bockelman et al, 2009). Furthermore, all have previously been detected in wastewater biofilms (Schwartz et al, 2003). These methods allow for a quick, low-cost analysis of local microbial communities and determine if a greater rate of AMR was present upstream (in the influent) or downstream (in the effluent) of a major Gainesville wastewater treatment plant (WWTP). 


\section{Materials and Methods}

\section{Site Selection and Tile Placement}

Following previously established procedures (Gallagher \& Reisinger, 2020), unglazed porcelain tiles were immersed in the stream at two sample sites near the University of Florida (UF) Main Campus. Six tiles were glued to bricks which were then attached via ziptie to concrete half blocks $\left(8 \mathrm{in}^{3}\right)$ to prevent tiles from becoming buried in sand. Both sites were along the Sweetwater Branch Creek in areas closely associated with the Gainesville Regional Utilities (GRU) Main Street Water Reclamation Facility, a wastewater treatment plant (WWTP) which handles local wastewater. Sampling locations were chosen from those environmental monitoring sites previously used in other work (Gallagher \& Reisinger, 2020). Site 1 (29³7'48.6"N $82^{\circ} 19^{\prime 20.9 " W}$; effluent), was located downstream of the GRU Main Street Water Reclamation Facility. Site $2\left(29^{\circ} 38^{\prime} 15.2^{\prime \prime} \mathrm{N} 82^{\circ} 19^{\prime} 04.7^{\prime \prime} \mathrm{W}\right.$; influent) was upstream of the same facility. Brick A (Tiles 1-3) and Brick B (Tiles 4-6) were placed at Site 1. Brick C (Tiles 7-9) and Brick D (Tiles 10-12) were placed at Site 2. A graphical depiction of both sites has been introduced in Figure 1. 


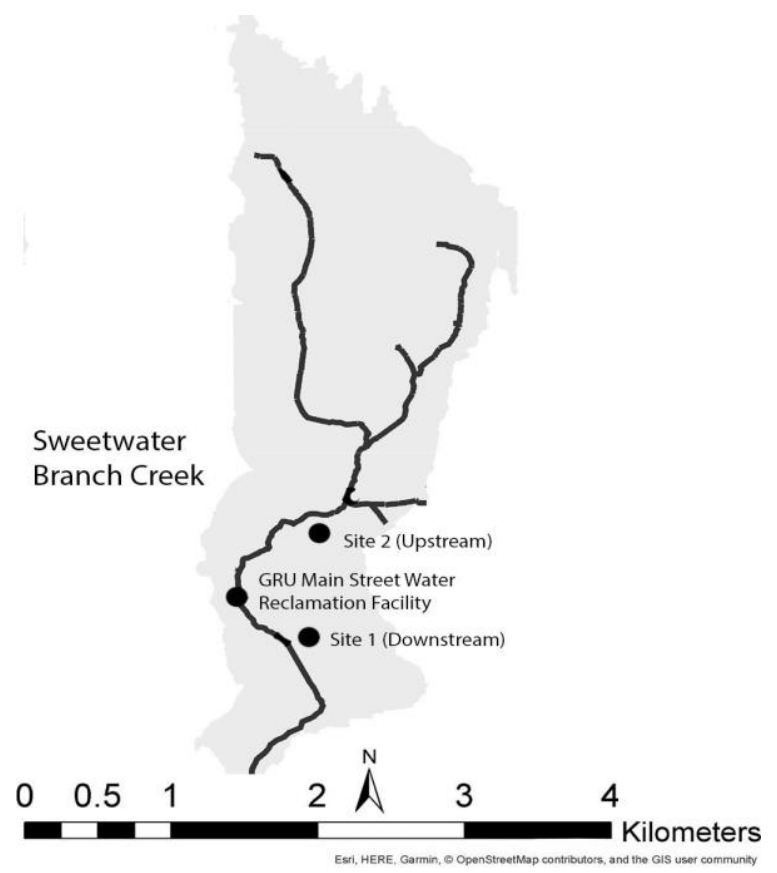

Figure 1. Brick A and Brick B (Tiles 1-6) were placed at Site 1 (downstream) and Brick $\mathrm{C}$ and Brick D (Tiles 7-12) were placed at Site 2 (upstream). Figure adapted from Gallagher \& Reisinger (Gallagher \& Reisinger, 2020).

\section{Colony Screening \& Development of Cell Lysates}

Tiles were left in the environment for one month to develop biofilms. After this time period, blocks with attached tiles were retrieved from the stream and transported back to the lab for analysis. Swabs from biofilms were cultured on R2A agar that had been inoculated with 10 $\mu \mathrm{g} / \mathrm{mL}$ of either ampicillin, methicillin, or vancomycin. Plates were kept at an ambient temperature $\left(\sim 25^{\circ} \mathrm{C}\right)$ and monitored daily for colony growth. Colony counts were conducted for four days before being refrigerated to prevent overgrowth. Select colonies were chosen for amplification of known AMR genes by polymerase chain reaction (PCR). With the exception of Tile 6, three colonies were selected per tile, one from each antibiotic plate, for a total of 35 colonies. Cell lysates were created by transferring single bacterial colonies via pipette to $20 \mu \mathrm{l}$ of sterile water in a $1.5 \mu \mathrm{l}$ microcentrifuge tube and boiling the contents in a heat block at approximately $100^{\circ} \mathrm{C}$ for $\sim 5$ minutes. Plate counts from both upstream and downstream sites were visualized in the statistical program $\mathrm{R}$ and evaluated for significant associations using an unpaired T test. 


\section{Genetic Analysis}

A subset of colonies that grew in the presence of antibiotics were tested for the presence of known antibiotic resistance genes. The cell lysates were used as the DNA template in a $25-\mu 1$ PCR containing QuickLoad Taq 2X Master Mix (New England Biolabs, Ipswich, MA) and 0.5 $\mu \mathrm{M}$ each primer. Cell lysates from culture plates with ampicillin were amplified with ampC primers (Knapp et al, 2010), lysates from vancomycin plates were amplified with vanA primers (Knapp et al, 2010), and lysates from methicillin plates were amplified with mecA primers (Bockelman et al, 2009). Thermal cycling was performed with a SimpliAmp thermal cycler (ThermoFisher Scientific, Waltham, MA) with an initial denaturation of $95^{\circ} \mathrm{C}$ for 5:00 minutes, followed by 35 cycles of $95^{\circ} \mathrm{C}$ for 30 seconds, $58^{\circ} \mathrm{C}$ for 30 seconds, and $72^{\circ} \mathrm{C}$ for 30 seconds. A final elongation was performed at $72^{\circ} \mathrm{C}$ for 5 minutes. PCR products were loaded into a $1 \%$ agarose gel for electrophoresis to determine the presence of amplified resistance genes.

\section{Results and Discussion}

\section{Growth of Antibiotic Resistant Colonies}

Biofilms developed on tiles attached to all four bricks placed along the Sweetwater Branch Creek. Tiles attached to Brick A (1-3) and Brick C (7-9) developed more substantial biofilm growth than Brick B (4-6) and Brick D (10-12) upon removal from the Sweetwater Branch Creek. Tiles on Brick D that were submerged in sand had less biofilm growth. Within four days at room temperature, all R2A enrichment plates developed bacterial colonies. Plates from Brick $\mathrm{C}$ produced colonies overnight in high numbers and were refrigerated after the first colony count. As described in Table 1, three cell lysates were generated for each tile (one per antibiotic). However, only 35 colonies were collected because mold overtook bacterial colonies on the Tile 6 ampicillin plate. Cell lysates were labeled as follows: tile number (01-12), sample number (0103), antibiotic type (vancomycin=V, ampicillin= A, methicillin=M), and brick number (A-D). No 0602AB exists due to an overgrowth of mold on the Tile 6 ampicillin plate section. A star $(*)$ has been used to indicate the presence of resistance genes in a colony.

Table 1. A full list of cell lysates. A star (*) indicates the presence of AMR genes.
Lysate ID
Colony Description
Lysate ID (Upstream)
Colony Description 
EMILY K. STONE

\begin{tabular}{|c|c|c|c|}
\hline 0101VA & Round red colony & $0701 \mathrm{VC}$ & Round off-white colony \\
\hline 0201VA & Round yellow colony & $0801 \mathrm{VC}$ & Round off-white colony \\
\hline 0301VA & Round off-white colony & $0901 \mathrm{VC}$ & Round off-white colony \\
\hline 0102AA & Round red colony & 0702AC & Round off-white colony \\
\hline 0202AA & Round off-white colony & 0802AC & Round off-white colony \\
\hline 0302AA* & Round orange colony & 0902AC & Round off-white colony \\
\hline 0103MA & Round yellow colony & 0703MC & Round off-white colony \\
\hline 0203MA & Round off-white colony & 0803MC & Round off-white colony \\
\hline 0303MA & Round yellow colony & 0903MC & Round yellow colony \\
\hline 0401VB & Round off-white colony & 1001VD & Round yellow colony \\
\hline $0501 \mathrm{VB}$ & Round yellow colony & 1101VD* & Round yellow colony \\
\hline 0601VB & Round red colony & $1201 \mathrm{VD}$ & Round orange colony \\
\hline 0402AB & Round yellow colony & $1002 \mathrm{AD}$ & Round off-white colony \\
\hline 0502AB & Round off-white colony & $1102 \mathrm{AD}$ & Round yellow colony \\
\hline $0403 \mathrm{MB}$ & Round off-white colony & $1202 \mathrm{AD}$ & Round red colony \\
\hline $0503 \mathrm{MB}$ & Round yellow colony & 1003MD & Round orange colony \\
\hline
\end{tabular}


$0603 \mathrm{MB}$

0701VC

The growth of bacterial colonies on enrichment media did not vary by site, regardless of the antibiotic used (p-value $>0.05$ ), (Table 2, Figure 2). This indicates that biofilm-forming bacteria within Sweetwater Branch commonly harbor resistance to the antibiotics ampicillin, methicillin, and vancomycin. In addition, this suggests that the effluent from the sewage treatment plant did not impact the number of culturable antibiotic-resistant bacteria.

Table 2. Results of unpaired T-test.

\begin{tabular}{lccccc}
\hline $\begin{array}{l}\text { Antibiotic } \\
\text { Type }\end{array}$ & T-Value & $\begin{array}{c}\text { Degrees of } \\
\text { Freedom (df) }\end{array}$ & P-Value & $\begin{array}{c}\text { Downstream Mean (\# } \\
\text { Colonies) }\end{array}$ & $\begin{array}{c}\text { Upstream Mean (\# } \\
\text { Colonies) }\end{array}$ \\
\hline Vancomycin & -1.3275 & 10 & 0.2138 & 37.67 & 79.17 \\
Ampicillin & -1.4541 & 10 & 0.1766 & 25.00 & 62.17 \\
Methicillin & -1.3782 & 10 & 0.1982 & 40.5 & 99.5 \\
\hline
\end{tabular}
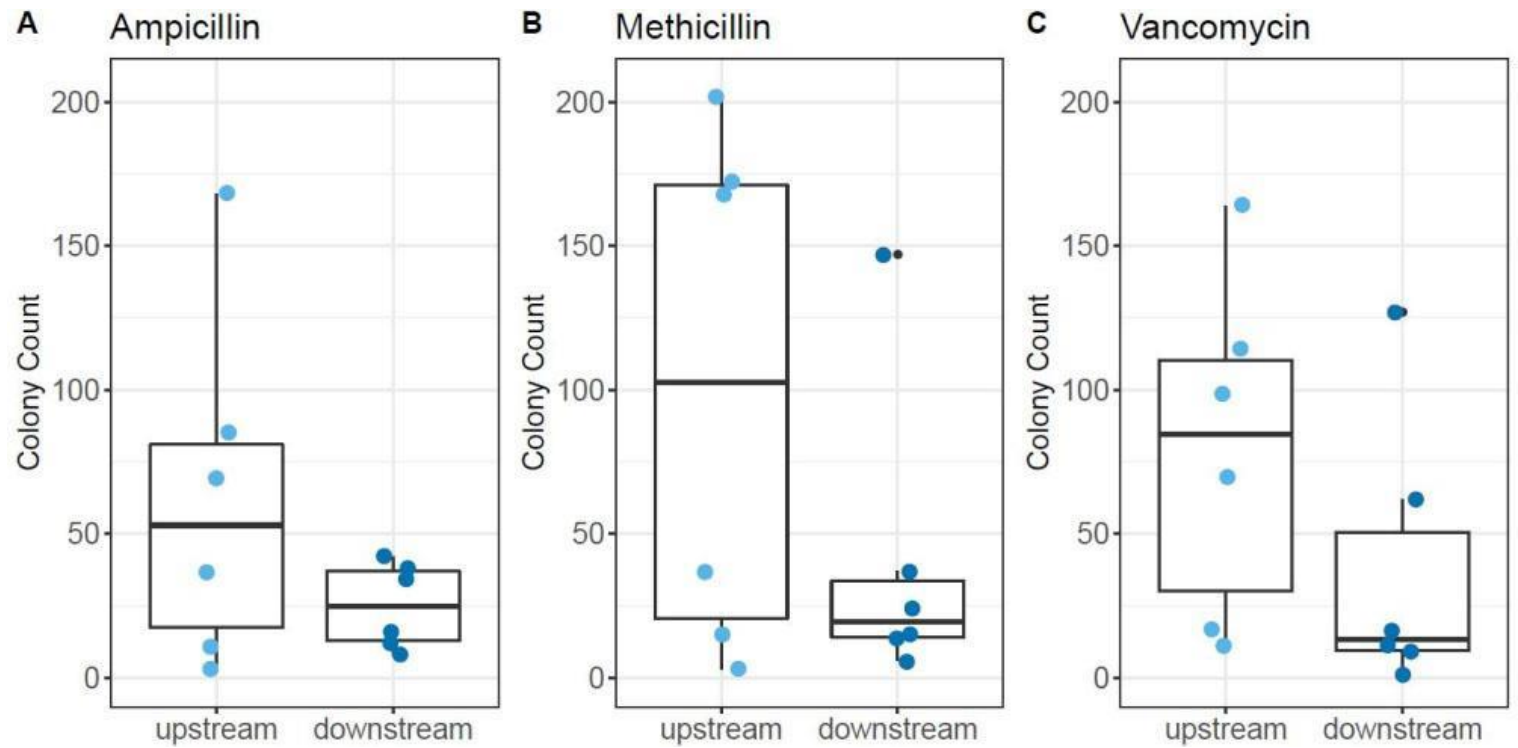
Figure 2. Box-and-whisker plots were produced in R to visualize colony counts from upstream and downstream sites for each antibiotic: ampicillin (A), methicillin (B), and vancomycin (C).

\section{PCR Amplification and Gel Electrophoresis}

PCR amplification and gel electrophoresis detected the presence of one colony carrying the ampC gene at Site 2 (Brick B, Tile 3) and one colony carrying the vanA gene at Site 1 (Brick D, Tile 11). Bands indicative of AMR genes have been identified with an arrow.

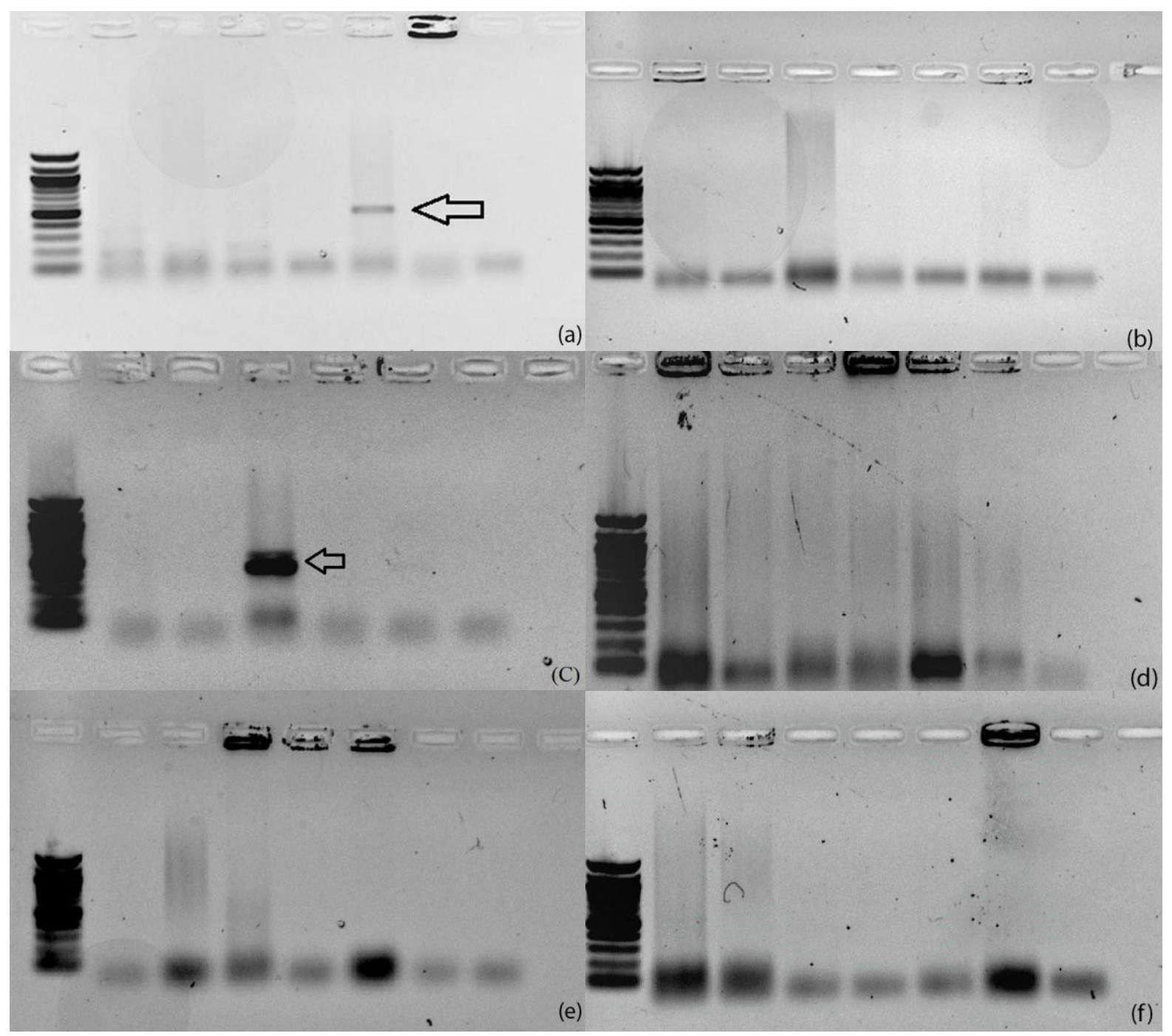

Figure 3. Gel electrophoresis for $v a n A$ gene (a-b), $\operatorname{amp} C$ gene (c-d), and $m e c A$ gene (e-f).

Results of gel electrophoresis for the $v a n A$ gene are described in Figure $3 \mathrm{a}$ and $3 \mathrm{~b}$. From the left, Figure 3a (Bricks A and D) includes the following samples in each well: ladder, 0101VA, 0201VA, 0301VA, 1001 VD, 1101VD, 1201VD, and vanA F/R primers. The band present in 1101VD indicates the presence of a resistance gene. From left, Figure 3b (Bricks B and C) 
includes the following samples in each well: ladder, 0401VB, 0501VB, 0601VB, 0701VC, 0801VC, 0901VC, and vanA F/R primers.

Results of gel electrophoresis for the $\operatorname{ampC}$ gene are described in Figure $3 \mathrm{c}$ and Figure $3 \mathrm{~d}$. From the left, Figure 3c (Bricks A and B) includes the following samples in each well: ladder, 0102AA, 0202AA, 0302AA, 0402AB, 0502AB, and $\operatorname{ampC~F/R~primers.~The~band~present~at~}$ 0302AA indicates the presence of a resistance gene. No 0602AB exists because fungal contamination made it impossible to sample colonies on the plate. From the left, Figure $3 \mathrm{~d}$ (Bricks C and D) includes the following samples in each well: ladder, 0702AC, 0802AC, 0902AC, 1002AD, 1102AD, 1202AD, and ampC F/R primers.

Finally, the results of gel electrophoresis for the mecA gene are described in Figure 3e and $3 \mathrm{f}$. From the left, Figure 3e (Bricks A and B) includes the following samples in each well: ladder, 0103MA, 0203MA, 0303MA, 0403MB, 0503MB, 0603MB, and mecA F/R primers. From the left, Figure 3f (Bricks C and D) includes the following samples in each well: ladder, 0703MC, 0803MC, 0903MC, 1003MD, 1103MD, 1203MD, and mecA F/R primers.

\section{Conclusion}

This preliminary environmental sampling project confirmed only a small number of AMR genes present in bacterial colonies from the Sweetwater Branch Creek. A greater amount of resistance was expected in influent (upstream) wastewater, as wastewater treatment can reduce the concentration of clinical antibiotics present. However, there was no significant difference in the number of colonies produced from either site sampled and the same level of resistance was detected at each site. Further sampling projects should be carried out to determine the prevalence of AMR in the Sweetwater Branch Creek.

While only two colonies sampled were found to contain AMR genes, bacterial colonies grew on all plates. This could be for a variety of reasons. First, it is possible that the concentration of antibiotics chosen was not sufficient to inhibit the growth of otherwise susceptible bacteria. Second, the colonies present may not have been susceptible to beta-lactams or glycopeptides; therefore, regardless of the concentration of antibiotics used, their growth may not have been inhibited. Such groups include Gram-negative bacteria, which have a plasma membrane instead of the thick peptidoglycan wall seen in Gram-positive species, among others (Kapoor, Saigal, \& Elongavan, 2017; Kahne et al, 2005). Lastly, other mechanisms of resistance, particularly nonspecific mechanisms such as efflux pumps, which are capable of removing nearly all classes 
of antibiotics, may have contributed to the survival of the colonies observed (Kapoor, Saigal, \& Elongavan, 2017; Schindler \& Kaatz, 2016).

The two antibiotics for which resistance was present (vancomycin and ampicillin) are of different classes. However, no resistance genes to methicillin were observed. While resistance to methicillin may be present in colonies not sampled, it is interesting that resistance genes were not observed to occur in any amplified colonies even though resistance to vancomycin, an antibiotic prescribed in many cases when methicillin fails to clear an infection, was present.

The COVID-19 pandemic necessitated many methodological changes to this project. While the results demonstrate only low levels of AMR in the Sweetwater Branch Creek, further analysis is needed to better illuminate bacterial community dynamics in the area. A 16S PCR to identify the bacterial species in each colony would be the logical next step. The colonies that were found to harbor resistance genes were of dissimilar morphologies and may be different species. Furthermore, expanding the range of subsequent studies, both in number of sites and in types of antibiotics, and increasing the duration of environmental sampling efforts would be a prudent next step.

\section{Acknowledgements}

This work was funded by the University of Florida's Center for Undergraduate Research through the University Scholars Program. All findings and conclusions reported in this paper are those of the author. The author wishes to thank Dr. Julie Meyer for providing guidance and oversight as a faculty mentor. Furthermore, the author wishes to thank Dr. A.J. Reisinger and Fay Belshe of UF Soil \& Water Science for their assistance in field site selection.

\section{References}

Aubertheau E., Stalder T., Mondamert L., Ploy M., Dagot C., \& Labanowski J. (2017). Impact of wastewater treatment plant discharge on the contamination of river biofilms by pharmaceuticals and antibiotic resistance. Science of The Total Environment, 579, 1387-1398.

https://doi.org/10.1016/j.scitotenv.2016.11.136

Baggs J, Fridkin SK, Pollack LA, Srinivasan A, Jernigan JA. Estimating National Trends in Inpatient Antibiotic Use Among US Hospitals From 2006 to 2012. (2016). JAMA, 176(11):1639-1648. doi:10.1001/jamainternmed.2016.5651

Balcázar J.L., Subirats J., \& Borrego C.M. (2015). The role of biofilms as environmental reservoirs of antibiotic resistance. Front. Microbiol. 6, 1216. https://doi.org/10.3389/fmicb.2015.01216

Bockelmann, U.; Dorries, H.H.; Ayuso-Gabella M.N., de Marcay M.S., Tandoi V., Levantesi C., Masciopinto C., Van Houtte E., Szewzyk U., Wintgens T., et al. (2009). Quantitative PCR monitoring of antibiotic resistance genes and bacterial pathogens in three European artificial groundwater recharge systems. Appl. Env. Microb, 75, 154-163. DOI: 10.1128/AEM.01649-08 
Burch K.D., Han B., Pichtel J., \& Zubkov T. (2019). Removal efficiency of commonly prescribed antibiotics via tertiary wastewater treatment. Environmental Science and Pollution Research, 26, 6301-6310. https://doi.org/10.1007/s11356-019-04170-w

Chambers H.F. (1997). Methicillin resistance in staphylococci: molecular and biochemical basis and clinical implications. Clinical Microbiology Reviews, 10(4), 781-791. DOI:

10.1128/CMR.10.4.781

Chow L., Waldron L., \& Gillings M.R. (2015). Potential impacts of aquatic pollutants: sub-clinical antibiotic concentrations induce genome changes and promote antibiotic resistance. Front. Microbiol. 6, 803. https://doi.org/10.3389/fmicb.2015.00803

Courvalin P. (2006). Vancomycin Resistance in Gram-Positive Cocci. Clinical Infectious Diseases, 42, S25-S34. https://doi.org/10.1086/491711

Fahrenfeld N., Ma Y., O’Brien M., \& Pruden A. (2013). Reclaimed water as a reservoir of antibiotic resistance genes: distribution system and irrigation implications. Front. Microbiol. 4, 130. https://doi.org/10.3389/fmicb.2013.00130

Gallagher, M. T., \& Reisinger, A. J. (2020). Effects of ciprofloxacin on metabolic activity and algal biomass of urban stream biofilms. Science of The Total Environment, 706, 135728. https://doi.org/10.1016/j.scitotenv.2019.135728

Gebreyohannes G., Nyerere A., Bii C., \& Sbhatu D.B. (2019). Heliyon, 5(8), e02192. https://doi.org/10.1016/j.heliyon.2019.e02192

Griffin D. W., Banks K., Gregg K., Shedler S., \& Walker B. K. (2020). Antibiotic Resistance in Marine Microbial Communities Proximal to a Florida Sewage Outfall System. Antibiotics, 9(3), 118. https://doi.org/10.3390/antibiotics9030118

Guo X., Yang Y., Lu D. Niu Z., Feng J., Chen Y., Tou F., Garner E., Xu J., Liu M., \& Hochella M.F Jr. (2018). Biofilms as a sink for antibiotic resistance genes (ARGs) in the Yangtze Estuary. Water Research, 129, 277-286. https://doi.org/10.1016/j.watres.2017.11.029

Kahne D., Leimkuhler C., Lu W., \& Walsh C. (2005). Glycopeptide and Lipoglycopeptide Antibiotics. Chem. Rev. 105 (2), 425-448. https://doi.org/10.1021/cr030103a

Kapoor G., Saigal S., \& Elongavan A. (2017). Action and resistance mechanisms of antibiotics: A guide for clinicians. Journal of Anaesthesiology, Clinical Pharmacology, 33(3), 300-305. https://doi.org/10.4103/joacp.JOACP_349_15

Kaushik D., Mohan M., Borade D. M., \& Swami O. C. (2014). Ampicillin: rise fall and resurgence. Journal of Clinical and Diagnostic Research, 8(5), ME01-ME3. https://doi.org/10.7860/JCDR/2014/8777.4356

Knapp C.W., Dolfing J., Ehlert P.A.I., Graham D.W. (2010). Evidence of increasing antibiotic resistance gene abundances in archived soils since 1940. Environ. Sci. Technol, 44, 580-587. https://doi.org/10.1021/es901221x 
Kulkarni, P., Olson, N. D., Raspanti, G. A., Rosenberg Goldstein, R. E., Gibbs, S. G., Sapkota, A., \& Sapkota, A. R. (2017). Antibiotic Concentrations Decrease during Wastewater Treatment but Persist at Low Levels in Reclaimed Water. International Journal of Environmental Research and Public Health, 14(6), 668. https://doi.org/10.3390/ijerph14060668

Lien L. T., Hoa N. Q., Chuc N. T., Thoa N. T., Phuc H. D., Diwan V., Dat N. T., Tamhankar A. J., \& Lundborg C. S. (2016). Antibiotics in Wastewater of a Rural and an Urban Hospital before and after Wastewater Treatment, and the Relationship with Antibiotic Use-A One Year Study from Vietnam. International Journal of Environmental Research and Public Health, 13(6), 588. https://doi.org/10.3390/ijerph13060588

Maal-Bared R., Bartlett K.H., Bowie W.R., \& Hall E.R. (2013). Phenotypic antibiotic resistance of Escherichia coli and E. coli 0157 isolated from water, sediment and biofilms in an agricultural watershed in British Columbia. 443, 315-323. https://doi.org/10.1016/j.scitotenv.2012.10.106

Marti E., Jofre J., \& Balcázar J.L. (2013). Prevalence of Antibiotic Resistance Genes and Bacterial Community Composition in a River Influenced by a Wastewater Treatment Plant. PLoS ONE 8(10): e78906. https://doi.org/10.1371/journal.pone.0078906

Marti E., Variatza E., \& Balcázar J.L. (2014). The role of aquatic ecosystems as reservoirs of antibiotic resistance. Trends in Microbiology, 22(1), 36-41. https://doi.org/10.1016/j.tim.2013.11.001

Nelson R.E., Hatfield K.M., Wolford H., Samore M.H., Scott R.D. II, Reddy S.C., Olubajo B., Paul P., Jernigan J.A., \& Baggs J. (2021). National Estimates of Healthcare Costs Associated With Multidrug-Resistant Bacterial Infections Among Hospitalized Patients in the United States, Clinical Infectious Diseases, 72(1), S17-S26, https://doi.org/10.1093/cid/ciaa1581

Schindler B.D \& Kaatz G.W. (2016). Multidrug efflux pumps of Gram-positive bacteria. Drug Resistance Updates, 27, 1-13.https://doi.org/10.1016/j.drup.2016.04.003

Schwartz T., Kohnen W., Jansen B., \& Obst U. (2003). Detection of antibiotic-resistant bacteria and their resistance genes in wastewater, surface water, and drinking water biofilms. FEMS Microbiology Ecology, 43(3), 325-335. https://doi.org/10.1111/j.1574-6941.2003.tb01073.x

Stapleton P. D., \& Taylor P. W. (2002). Methicillin resistance in Staphylococcus aureus: mechanisms and modulation. Science Progress, 85(Pt 1), 57-72. https://doi.org/10.3184/003685002783238870

Van Boeckel T.P., Brower C., Gilbert M., Grenfell B.T., Levin S.A., Robinson T.P, Teillant A., \& Laxminarayan R. (2015). Global trends in antimicrobial use in food animals. Proceedings of the National Academy of Sciences, 112(18) 5649-5654; DOI: 10.1073/pnas.1503141112

Van Boeckel T.P., Gandra S., Ashok A., Caudron Q., Grenfell B.T., Levin S.A., Laxminarayan R. (2014). Global antibiotic consumption 2000 to 2010: an analysis of national pharmaceutical sales data. Lancet Infect Dis. 2014 Aug;14(8):742-750. doi: 10.1016/S1473-3099(14)70780-7. Epub 2014 Jul 9. Erratum in: Lancet Infect Dis. 2017 Sep;17(9):897. PMID: 25022435.

von Wintersdorff C.J.H., Penders J., van Niekerk J.M., Mills N.D., Majumder S., van Alphen L.B., Savelkoul P.H.M., \& Wolffs P.F.G. (2016) Dissemination of Antimicrobial Resistance in Microbial Ecosystems through Horizontal Gene Transfer. Front. Microbiol. 7, 173. https://doi.org/10.3389/fmicb.2016.00173 
World Health Organization. (2014). Antimicrobial drug resistance. Secretariat.

Zhang XX., Zhang T., Fang H.H.P. (2009). Antibiotic resistance genes in water environment. Applied Microbiology and Biotechnology, 82, 397-414. https://doi.org/10.1007/s00253-008-1829-z 